\title{
Domestic Model for Provision of the National and Public Security at the Present Stage of Political Modernization
}

\author{
Elena V. Efanova \\ Sergey A. Pankratov \\ Sergey l. Morozov \\ Volgograd State University. Volgograd, Russia; Email: sci.publ@gmail.com
}

Alexander V. Maklachkov

Military university of the MD RF, Moscow, Russia; Email: sci.publ@gmail.com

Doi:10.5901/mjss.2015.v6n6s4p577

\begin{abstract}
In the context of the global development processes, shaping the new threats and risks for the individual, society and state development, Russia as a protector of the national prosperity is proceeding to the new state policy in the field of national and public security. However, the modern Russian state is characterized by the non-complex structuring but socio-political anomie, the public capital being distributed unfairly. The divide is negative in character. Moreover, it is non-productive and it does not prevent from the further disintegration of the social texture. As a result, on the one hand, there is a sense of relative and temporary well-being, and on the other hand, there is a feeling of non-participating in the process of shaping the future image. In addition to that, there remains a hidden uncertainty whether we ought to consider a person to be an object or a subject of security in this "national formula".
\end{abstract}

Keywords: political modernization, state, national and public security, international security, national interests.

\section{Introduction}

Over the years, there have been discussions on the essential issues of the domestic internal political development in Russia, the provision of national and public security being one of them. The time has come for Russia to renovate the political system, to establish and to expand the modern institutions and practices to ensure a timely and adequate response of the political system to the changing conditions of modern life. However, the internal political transformations are extremely controversial, consequently the problem of national interests and priorities finding on the way to RF national and public security ensuring is made actual. Besides, the structural crisis of the international security system has markedly manifested itself which adds to the importance of more urgent reconsideration of the conceptual foundations of security, requires the revaluation of the resources and mechanisms of its provision, identification and intelligibility of the national interests, a clear domestic and foreign policy prioritization.

\section{Methods}

We used the provisions of the political realism school ( $\mathrm{H}$. Morgenthau), justifying the objective nature of the national interests as a theoretical and methodological basis. The content of the national interests of Russia and their implementation practice is presented in the papers of A.G. Zadokhin, O.M. Litvishko, A.V. Fedyakin, A.A. Chekulaev in the Russian science. Among security researches the foreign scholars (K. Waltz, S. Walt) and Russian (L.V. Deriglazova, V.N. Panin, A.A. Sergunin) are worth mentioning. The general scientific methods, secondary analysis of empirical data collected at the national Russian level were used. 


\section{Discussion}

As a result of the radical socio-political transformation of the 1990s in Russia, diversification of both economic and political resources took place. In these conditions two parallel trends gained traction. On the one hand, decentralization, which manifested itself in the "parade of sovereignties" and on the other hand, diversification of the regional political processes took place in the country. In the early 2000s the vector of political development changed. President V.V. Putin's recentralization policy became a priority (Panov, 2006). In this context, the question arises, what is the strategy of the state to ensure Russia's national security in the conditions of the selected path.

In the times of the Soviet Union, theory and practice of the Soviet political activities dealt exclusively with the problems of public but not national security and with the issues of international security in the foreign policy (Vakhrameev, 2001). In other words, the complexity of the transition from the traditional system of state security to a new system of national security is seen in the fact that the state considers not a person, not the society but itself to be the security priority object. The consequence of this and the most important feature of the political development of post-Soviet Russia appeared to be the transitional regime for which the interests of the state and society were different which was expressed in the intertwining of mutually exclusive principles of life. This discrepancy was formed historically, influenced by the existence experience in the imperial and post-imperial political space.

The Russian history proves that the nationhood formation process from the politically, culturally and ethnically diverse elements implied the dominance of the view in the political culture of the unity of the state to be the vertical power structure strengthening. On the one hand, we see personification and indivisibility of the authorities which they associate with the historically established "Russian system". On the other hand, personified power is shaped and legitimized in a democratic way, as all other ways of its legitimization proved to be historically exhausted. However, underdevelopment of democratic institutions in Russia inevitably results in disappointment in them and emergence of "strong hand" hankering in the society craving and hopes that the authoritarian leader is able to ensure stability and order (Shevtsova, 2004).

In the conditions when the society appeared to be socially and ideologically split, V.V. Putin selected as the basis of the state policy the principle of "social contract" being the consolidation of the state, business and society, which allowed him on the one hand, to preserve the social obligations and on the other hand, to maintain the postulates of the liberal ideology. The desire to meet the "humanistic values, ample opportunities for personal and collective success, hard won civilization standards" is from the standpoint of the President, the priority task for Russia as a country of the European civilization (http://www.kremlin.ru/).

There has been a shift from the selected autocracy of B.N. Yeltsin to the bureaucratic-authoritarian regime established by V.V. Putin. After this regime had been formed the "space for democratic vector strengthening in Russia shrunk dramatically. There are reasons to fear that in the event of the economic and social crisis, the nationalist populist way of solving Russian problems will prevail". "... Having strengthened his control over the state, V.V. Putin alone will be responsible for Russia. He will have no one to blame for the failures. Meanwhile, the higher the responsibility, the greater is the risk of losing trust and support of the society in the event of failures and errors. Having tried to shift the responsibility onto the government and the parliament, the leader will only discredit his own regime, as long as all institutions are explicit extension of the executive power" (Shevtsova, 2004). On the other hand, the President's actions are induced by the needs and expectations of the society. "Today the authorities are doing what the society wants" (Shestopal, 2004). The society is not prepared for political democracy, since "firstly the responsibility and habit to living in conformity with the law is bred with the nation and then the state is transferred to political freedom, and not vice versa" (Pastukhov, 2006). Consequently, there are reasons to believe that the 2000s are characterized by the artificial containment of the democratic development pace in Russia. Against this background, "national security" is understood not as a condition in which smooth and successful development of all social and public institutions is guaranteed but optimal conditions for existence and development of the individual, society and state are created, and in the traditional sense it is security in the military sphere.

From the viewpoint of the current state of interstate relations, military security should characterize the country's ability to counteract the war outbreak, embroilment in the war or at least reduce to minimum its destructive consequences. In other words, military security characterizes, on the one hand, state's own resources to counteract the military power of other countries, and on the other hand, the condition of the interstate relations, especially their political and military state, i.e. military security is directly connected with the state of military-political sphere at the global, regional levels and with the national defense capability.

Security at all levels is the key problem of the entire system of international relations. Increased interdependence of the states and the need to address the global issues jointly is the result of globalization but nevertheless, it does not mean that the security problems have been resolved. Moreover, as new different threats and dangers emerge in the 
modern world, the problem of safe human existence is becoming increasingly important. Security threats are closely connected with the national interests of the state, including those outside its borders. In each case, to eliminate the threats special instruments and methods are required. The national interests of any country is not a static concept, they are dynamic, they absorb the conditions of the internal and external political situation and they are transforming together with those conditions.

The national interest in ensuring the stability of the constitutional order, territorial integrity and sovereignty remains unshakeable. It should be mentioned that despite the fact that in recent years there have been no major conflicts over the secession of territories in Russia, the threat of the territorial integrity today exists. Among the causes for such threats are: "retaining of the normative legal base of ethno-political disintegration of the borderline area of the country"; "oligarchization (and feudalization) of the regional authorities"; "critical from the standpoint of Russia's territorial security differences in the infrastructure development of borderline regions, especially between the European and Asian parts of the country" (Tynianova, 2010).

Undoubtedly, regardless of the causes, the threat of separatist sentiments in Russia persists. According to the study carried out in 2012 by the Higher School of Economics jointly with Institute of Social and Economic Studies of Population at the Russian Academy of Sciences, the highest separatist sentiments are found on the territory of the Republic of Ingushetia and Chechnya - about 1/3 of the total population of the republics are in favor of secession from the Russian Federation (in Ingushetia 17\% of respondents are in favor of complete separation to become an independent state, and $15 \%$ are for the separation as a part of the Federation of the Caucasian Peoples, in the Chechen Republic the figures are $15 \%$ and $8 \%$ respectively) (Khaikin S.R. Popov N.P., 2012).

What concerns the issue of territorial integrity, the Russians are virtually unanimous. According to the survey conducted in 2013, $93 \%$ of respondents believe that it is necessary to defend the territorial integrity of the Russian Federation by all available means. At the same time, $57 \%$ believe that today there are various threats to the integrity of the state (the highest indicator here is so-called "Chinese Issue" - 15\% of respondents believe that migrants from China are threatening the territorial integrity of Russia). In general, if we consider other threats to the Russian Federation's integrity they appear to be external threats, in addition to the "Chinese Issue", some people assume Russian-Japanese dispute over the Kuril Islands (7\%) to be the threat, other threats come from the United States (6\%), from Europe (4\%). Territorial integrity and terrorism is seen as a threat by only $3 \%$ and $2 \%$ of respondents living in Russia's regions respectively (http://fom.ru/Politika/11086)

It is also important that implementation of Russia's domestic policy of national security has not only a local but an international dimension: destruction of the old international security architecture and lack of the new strong mechanism to support security, absence of clear approaches to evaluate the danger of transnational problems and overall vagueness and uncertainty of the future world order. The bipolar world built on the balance of the superpowers of the USA and the USSR disappeared together with the end of the "Cold War" and this led to the emergence of completely different security threats which must be addressed on the basis of the nonlinear nature of the world integrity. At the same time, concernment only in the national security is similar to striving for ethnic and cultural security: it divides rather than unites people. Defending ethnic and cultural identity is increasingly turning into the source of threat for the individual and society, undermining regional and international security (Panarin, 1998). To counteract the growing number of security challenges, it is insufficient nowadays to adhere to the old policy. In the present conditions it is necessary to attend to not only saving our own, national borders, but the main thing is to develop international institutions and cooperation, to improve international law to maintain peace and security.

In the current international situation, Russia, in the presence of the potential dangers and tangible military threats is to restore the system of national security protection, amongst other things to possess nuclear power which can bring the set damage to any aggressor state or the coalition of states at all times.

It is acknowledged in the in the "National Security Strategy of Russia till 2020" that "in order to ensure state and public security: they improve the structure and activities of the federal executive bodies; implement the National AntiCorruption Blueprint; develop the system to identify and counteract the global challenges and crises, including international and national terrorism, political and religious extremism, nationalism and ethnic separatism; create mechanisms to prevent and neutralize the social and inter-ethnic conflicts; establish a long-term concept of integrated development and improvement of law enforcement bodies and secret services, strengthen social protection of the employees, improve scientific and technical support to law enforcement bodies, adopt advanced specialized equipment and technologies, develop the system of professional training of personnel for state and public security sector; enhance safety measures at the enterprises, organizations and institutions of the military-industrial, nuclear, chemical and atomicenergy sectors, as well as vital infrastructure; improve social responsibility of public security institutions" (http://www.scrf.gov.ru/documents/99.html). Attaining this strategic goal of the state policy is possible by applying the 
corresponding adjustment of the existing rules and regulations and development of the new legislation meeting the requirements of the present-day realities.

The basic requirements of institutional changes include recognition of the critical role of the government control of economic development; government's commitment to economic development; accounting of institutional transformation costs; review of efficiency of the current control.

Governmental control is one of the most important ensuring instruments of a state. The activities of the controlling authorities are governed by a whole system of normative legal enactments (Larionova, Napolskikh, Yalyalieva., 2015).

Governmental control is performed by officials representing the authorized bodies, within their competences, by collecting explanations, checking the accounting and reporting information, inspecting the premises and territories used to gain income (profit), and by using other instruments provided by the law. One of the most significant areas of governmental control is financial control. Financial control is traditionally considered as a part of the governmental control system which covers the sphere of formation, distribution and use of the monetary funds. Financial control is control of the legality and appropriateness of the activities performed in the sphere of formation, distribution and use of the monetary funds of the state and municipalities, which is aimed at efficient social and economic development of the country and its regions. Representing a constituent part of the economic management, financial control ensures the interconnection between companies and the governmental bodies that have the corresponding rights and authorities (Murzina, Larionova, Yalyalieva, 2015).

The model of international security proposed by Russia at the official level is a model of global security. Thus, it is said in the RF Foreign Policy Concept that "Russia is pursuing a policy aimed at creating a stable and sustainable system of international relations based on the international law and on the principles of equality, mutual respect, non-interference in the internal affairs of the states" (The Foreign Policy Conception of the Russian Federation, 2015). In this context the special role is allocated to such organization as the United Nations - "global challenges and threats require the adequate response of the world community, their joint efforts with the central coordinating role belonging to the UN and with the consideration of the objective interrelatedness of security issues, sustainable development and protection of human rights". Speaking about the role of the UN in taking decisions on the international security, we mean the universal character of the organization and all-round membership of states in the UN. The fact itself that the United Nations is conferred responsibility on security in the world proves the consistent implementation of the universal model of international security by Russia - "Russia sees the United Nations and the Security Council of the United Nations to be the central element of the stable system of international relations based on respect, equality and mutually beneficial cooperation of the states, resting on the civilized political instruments for solving global and regional critical situations"( The National Security Strategy of the Russian Federation till 2020, 2009).

Similar is the thesis proposed by V.V. Putin in his Address to the Federal Assembly - "... we do not pretend to be some superpower, understood as a claim for the global and regional hegemony, we do not encroach on anyone's interests, we do not impose our patronage, we do not try to teach anyone how to live. However we will strive to be leaders defending the international law, strive for respect to the national sovereignty, independence and identity of the peoples" and "...Russia is ready to work together with all the partners to ensure common, equal and indivisible security" (Address of the RF President Vladimir Putin to the Federal Assembly, 2013).

There is an opinion that Russia advocates the idea of the multipolar world and the system of global security, for rejecting the arms race, for the reason that today Russia is not in a position to compete for global leadership with the United States (Chekulaev, 2011). However, Russia maintains its position, continues to play an important part in the global process thanks to the legacy of the Soviet diplomacy, military, scientific and technological potential and specific geographical position on the continent. Others tend to believe that peace is unattainable with the leadership of the USA "But, despite the steep claims, the USA is no longer capable to fight for the planetary hegemony. ... the New power centers strengthen credibility - Europe, China and Far East in general. Anyway, Americanization of the world increasingly faces other models of globalization, because the world is moving towards multipolarity" (Arsentyeva, 2009)

In addition to building up a universal international security, Russia consistently advocates the thesis of the need to create at the international regional level a collective security model supported by the CSTO - "Collective Security Treaty Organization is seen to be the main interstate instrument to resist regional military-political and military-strategic challenges and threats, including measures against illegal drug trade and psychotropic substances" (The National Security Strategy of the Russian Federation till 2020, 2009)

While implementing Russia's "new" foreign policy it is important to establish so-called "Asian rearward area" - "the new balanced multi-vector foreign policy of the Russian Federation aimed at building close relations with the West countries realizing the necessity to develop strategic cooperation with the informal leader of the Asian countries - China is the only fuse from deterioration of Russia's foreign policy position" (Arsentyeva, 2009). It is especially worth paying 
attention to this fact after the escalation of the conflict in Ukraine and the Western countries' reaction.

Prior to the events in Ukraine and in the Crimea, researchers agreed that Russia's foreign policy is aimed at the entry into the international community on equal terms, without a single hint of leadership - "...Russia's position in the world and the international security system are being reframed. V. Putin ... emphasizes not Russia's role as an independent power center but its integration into the world community" (Zevelev, 2002). Currently, the direction of the expert rhetoric has changed. Russia has critically changed its foreign policy doctrine. Now Russia's goals do not coincide with the earlier proposed goals. The actions of Russia take roots not from the simple desire to annex the territory but from the whole broad vision - "from the range of conceptions that have emerged in the intellectual discourse of the post-Soviet Russian identity over the last 20 years, eventually those conceptions were selected which were assumed to be the most appropriate for legitimization of the system and independence, power and dominance of the Russian state. The first conception is the idea that Russia should be a strong, independent great power being the stronghold of all conservative forces fighting against revolutions, chaos and liberal ideas embarked by the USA and Europe. The second conception is the idea of the large Russian world and Russian civilization differing from the Western one, spreading beyond the borders of the Russian Federation" (Zevelev, 2003).

\section{Results}

Russia is implementing its national interests specified in the Strategy-2020 in the system of universal international security to be transformation of Russia into a world power, the development of democracy, maintaining equal and partner relations, sacrosanctity of the territorial integrity and national sovereignty. On the one hand, the national interests today constitute the basis of politics, they are being compared to. The national interests of Russia are in the centre of the diplomatic relations, and the "capability and capacity to implement them successfully is an indicator of the status of the state in the emerging system of international relations" (Chekulaev, 2011) On the other hand, implementation of the national interests, including those of Russia, today stands against the world globalization process, "under which the efforts to reduce the role of the national states in economy and in other spheres of social life are intensified" (Semyaninov, 2012)

\section{Conclusions}

- The problem of relations between the individual, society and state is especially significant and important for Russia. The core of those relations is the balance, parity of interests of an individual, society and state. It is this formula that is the foundation of the national interests. It aims at consolidation of the society, its sustainable development and security. However, the political and ideological foundations of the Russia society as a synthesis of the liberal and conservative values, principles and guidelines do not provide the desired harmony in the country and do not constitute the political and legal formula of the national consensus.

- Feelings of confusion, general frustration, hostility and aggression have become predominant in the mass consciousness. As the authoritarian character of the political authorities and the "political state" are restored and the illusion of the order establishment emerge.

- National security is the form of the generalized criterion characterizing the country's ability to maintain the integrity, to solve independently political, economic, social and other problems and act as an individual subject of the system of international relations. Russia deals with that aspect of national security which is directly connected with the use of military power and armed violence. In other words, military security characterizes the country's ability and its armed forces to counteract or prevent damage to its national security by means of armed violence. This is its main specifics.

- Protection of the national interests by means of armed violence, country's military security remains to be one of the priorities of the RF national authorities' activities, so the main ways to strengthen outline country's military security are to be outlined in detail. Still, military security itself is not a self-sufficient characteristic and criterion therefore, without taking into account the individual and society's interests it degenerates into a nonentity. Military security ought to be considered not as a goal but as a tool, a free in his/her development individual being the goal.

- The 2020 Strategy represents the national interests of the RF. These interests are: development of democracy and civil society, ensuring the national economy competitiveness, ensuring the constitutional system stability and territorial integrity and transformation of Russia into the world power and maintaining partnership relations 
with other world subjects. It is important that the external and internal interests of Russia should be an overall interconnection.

- National interests' implementation process takes place in the certain environment to be the system in international security. Russia as one of the world's players defends the necessity of the global security system implementation supported by the UN. To implement the international regional security measures, Russia is establishing a collective model supported by the CSTO. The character of the national interests' implementation system is made in terms of the public opinion enounced in the governmental policy to secure the national interests and supported by the country's citizens.

\section{Acknowledgement}

This article was written within the grant of the Russian Humanitarian Foundation \# 15-13-34011.

\section{References}

Address of the RF President to the Federal Assembly of the Russian Federation. 25.04.2005 / [Electronic Resource] - Accessed: http://www.kremlin.ru/ appears /2005/04/25/1223_type63372type82634_87049.shtml. - Screen Title.

Address of the RF President Vladimir Putin to the Federal Assembly [Electronic Resource] / Accessed: http://www.rg.ru/2013/12/12/ poslanie.html. - Screen Title.

Arsentyeva I(2009).I. Russia between the West and the East in the Globalized World: the National Security Strategy // Proceedings of Herzen Russian State Pedagogical University. 2009. No.97.

Chekulaev A.A. (2001)The National Interests of Russia in the Conditions of the New International Relations Systems Formation: Challenges and Priorities for Implementation: Candidate of Political Science Dissertation. - Moscow, 2011.

Khaikin S.R. Popov N.P. (2012) Protest Sentiments in the North Caucasus: the General and The Particular (Part I) // Monitoring of Public Opinion: the Economic and Social Changes. 2012. No.4.

Larionova N. I., Napolskikh D. L.and. Yalyalieva T.V. (2015)Theoretical approaches to improving Government control systems for educational Clusters development. Actual problems of economics. № 4, 2015. edition pp 285-288

Murzina E.A., Larionova N.I, YalyalievaT.V. (2015) Supervising the Efficiency of Governmental Control of Regional Economy: Legal Aspects and Economic Essence. Mediterranean Journal of Social Sciences.Vol 6, March 2015 edition pp370-375

On the Territory of Russia and its Integrity [Electronic Resource]. - Accessed: http://fom.ru/Politika/11086. - Screen Title.

Panarin S.A. Sacurity and Ethnic Migration // Pro et contra. 1998. Vol. 3. No.4.

Panov P.V. (2006) Regional Political Processes in the Russian Federation in "Putin's Era": Unification or Diversification? // POLITEKS. 2006. No. 4.

Pastukhov V.B. (2006) Putin's Third Term as an Alternative to Political Hypocrisy. A Speech of a Political Cynic // Political Researches. 2006. No. 2.

Semyaninov V.P. (2012) On the Conditions Ensuring the National Interests of Russia // Bulletin of TSU. 2012. No. 5.

Shestopal Ye.B. (2004)An Authoritarian Request for Democracy, or Why Oranges are not Grown in Russia // Political Researches. 2004. No. 1.

Shevtsova L.F. (2004) Change of the Regime or the System? // Political Researches. 2004. No.1.

The Foreign Policy Conception of the Russian Federation [Electronic Resource] / Accessed: http://www.garant.ru/products/ipo/prime/ doc/70218094/. - Screen Title.

The National Security Strategy of the Russian Federation till 2020 [Electronic Resource] / Accessed: http://www.rg.ru/2009/05/19/ strategia-dok.html. - Screen Title.

The site of the Security Council of the Russian Federation [Electronic Resource]: - Accessed: http://www.scrf.gov.ru/documents/99.html. - Screen Title.

Tynianova O.N. (2010) The National Sovereignty and National Borders in the Era of Globalization // Age of Globalization. 2010. No. 1.

Vakhrameev A.V. (2001)On the Issue of National Security of the Russian Federation (declarations and reality) // Social-humanitarian Knowledge. 2001. No.1.

Zevelev I.A. After the Crimea: The New Foreign Policy of Russia [Electronic Resource]. - Accessed: http://www.vedomosti.ru/newspaper/ article/656031/novaya-vneshnyaya-politika-rossii. - Screen Title.

Zevelev I.A. (2002)Russia and the USA at the Beginning of the New Century: Anarchy is the Mother of Partnership // Pro et contra. 2002. No. 7. 